\title{
NANOPARTICLES GUIDED PRECISE TRANSPLANTATION OF VARYING NUMBERS OF MESENCHYMAL STEM CELLS INTO POST-TRAUMATIC SYRINX IN SPINAL CORD INJURY RAT
}

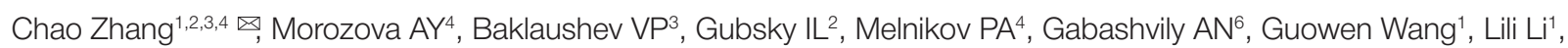
Haixiao $\mathrm{Wu}^{1}$, Xin Wang ${ }^{5}$, Chekhonin VP2,4

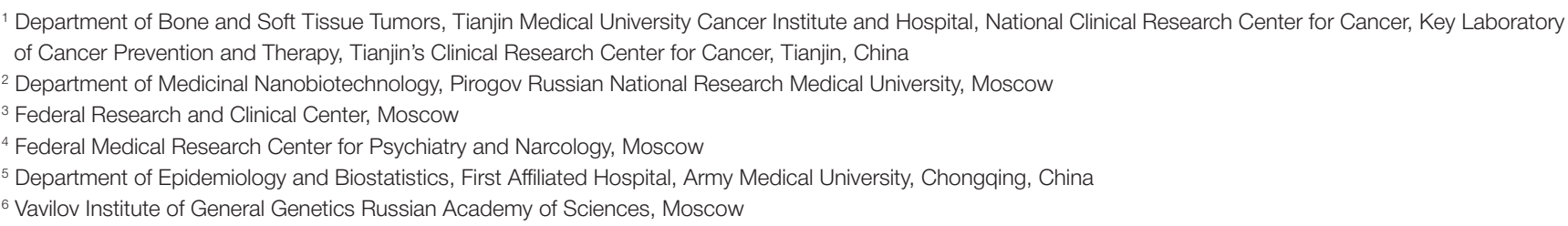

Spinal cord injury (SCl) is a traumatic injury to the spinal cord which is not a consequence of the disease. Mesenchymal stem cells (MSCs) have gradually become one of the most used stem cells in research and clinic trial. Based on the previous reports employed the cells ranged from $4 \cdot 10^{5}$ to $1 \cdot 10^{6}$, the present study was performed to figure out the best number of MSCs for transplantation of the chronic SCl. Magnetic nanoparticles were used for proving the precise transplantation strategy. Using magnetic resonance imaging (MRI), diffusion tensor imaging (DTI), diffusion tensor tractography (DTT), and behavior testing evaluations, we focused the effect of varying numbers of MSCs on reducing lesion cavity and post-traumatic syrinx formation, suppressing glial scar formation, enhancing neuronal fibers remodeling, promoting axonal regeneration and sprouting, improving vascularization, ameliorating the neuronal factors expressional level, and function improvement. Magnetic nanoparticles were precisely transplanted into the posttraumatic syrinx (PTS). MSCs can restore function after chronic SCl through stimulating the regeneration and sprouting of the axons, reducing the formation of PTS. The effect of MSCs on PTS management and functional improvement post chronic SCI was cell number-dependent, and within the range of $4 \cdot 10^{5}$ to $1 \cdot 10^{6}, 1 \cdot 10^{6}$ cells were proved to be the best dose.

Keywords: mesenchymal stem cells; spinal cord injury; cell transplantation; nanoparticles

Funding: the present study was sponsored by China Scholarship Council (201406940004), and Russian Scientific Foundation (16-15-10432).

$\varangle$ Correspondence should be addressed: Chao Zhang

Huanhu Xi Road, Hexi Area, Tianjin, China, 300060; drzhangchao@tmu.edu.cn

Received: 26.08.2018 Accepted: 25.09.2018

DOI: $10.24075 /$ brsmu.2018.084

\section{НАНОЧАСТИЦЫ СПОСОБНЫ НАПРАВЛЯТЬ ТРАНСПЛАНТИРОВАННЫЕ МЕЗЕНХИМАЛЬНЫЕ СТВОЛОВЫЕ КЛЕТКИ В ПОСТТРАВМАТИЧЕСКИЙ СВИЩ У КРЫС С ПОВРЕЖДЕНИЯМИ СПИННОГО МОЗГА}

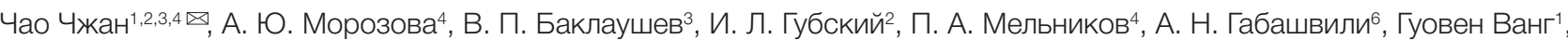 \\ Лили Ли ${ }^{1}$, Хайсяо У'ำ, Ксин Ванг ${ }^{5}$, В. П. Чехонин ${ }^{2,4}$ \\ Кафедра опухолей костей и мягких тканей, Онкологический институт и госпиталь Тяньцзиньского медицинского университета, Национальный клинический \\ исследовательский центр рака, Главная лаборатория профилактики и лечения рака, Тяньцзиньский клинический исследовательский центр рака, Тяньцзинь, Китай \\ Кафедра медицинской нанобиотехнологии, Российский национальный исследовательский медицинский университет имени Н. И. Пирогова, Москва \\ ${ }^{3}$ Федеральное медико-биологическое агентство, Москва \\ ${ }^{4}$ Национальный медицинский исследовательский центр психиатрии и наркологии имени В. П. Сербского, Москва \\ ${ }^{5}$ Кафедра эпидемиологии и биостатистики, Первая больница медицинского университета Сухопутных войск, Чунцин, Китай \\ ${ }^{6}$ Институт общей генетики имени Н. И. Вавилова РАН, Москва
}

Травма спинного мозга (ТСМ) - это травматическое повреждение, не являющееся следствием заболевания. Мезенхимальные стволовые клетки (МСК) становятся одним из наиболее используемых типов стволовых клеток как в научных исследованиях, так и в клинических испытаниях. С учетом предыдущих работ, в которых использовали от $4 \cdot 10^{5}$ до $1 \cdot 10^{6}$ кл., целью данного исследования было определить количество МСК, оптимальное для трансплантации при хронической ТСМ. Магнитные наночастицы (НЧ) использовали для доказательства точности проведенной трансплантации. С помощью магнитно-резонансной томографии (MPT), дифффузионно-тензорной визуализации (DTI), диффузионно-тензорной трактографии (DTT) и поведенческих тестов мы проверили влияние различного количества MCK на уменьшение пораженной полости и посттравматического свища, подавление формирования глиального рубца, усиление ремоделирования нейронных волокон, содействие регенерации и прорастанию аксонов, улучшение васкуляризации, повышение уровня экспрессии нейронных факторов и улучшение функционирования системы. Магнитные НЧ были точно трансплантированы в посттравматический свищ (ПТС). МСК могут восстанавливать функцию после хронической ТСМ посредством стимуляции регенерации и прорастания аксонов, уменьшая образование ПТС. Таким образом, влияние МСК на ПТС и функциональное улучшение после хронической ТСМ зависит от количества клеток, и в диапазоне от $4 \cdot 10^{5}$ до $1 \cdot 10^{6}$ наилучшей дозой является $1 \cdot 10^{6}$.

Ключевые слова: мезенхимальные стволовые клетки; травма спинного мозга; трансплантация клеток; наночастицы Финансирование: исследование поддержано Китайским стипендиальным советом (№ 201406940004) и Российским научным фондом (№ 16-15-10432).

$\bigotimes$ Для корреспонденции: Чао Чжан ул. Хуанху Си, Район Хэси, Тяньцзинь, Китай, 300060; drzhangchao@tmu.edu.cn Статья получена: 26.08.2018 Статья принята к печати: 25.09.2018

DOI: $10.24075 /$ vrgmu.2018.084 
Previous epidemiological research suggested the annual incidence in China of spinal cord injury (SCI) reached 23.7 cases per million people [1]. The global annual incidence was recently reported range from 9.2 to 246 cases per million [2]. Almost half of the cases result in complete loss of function below the injury level. First-year medical costs for a high tetraplegic patient and a paraplegic patient are estimated at over $\$ 800,000$ and $\$ 300,000$ respectively [3]. In the past decades, the mortality rate in the first year has been successfully reduced. However, $\mathrm{SCl}$ is still regarded as untreatable condition [4].

The pathophysiology of SCl can be defined as a biphasic process: (1) the primary phase which involves the initial mechanical injury and (2) the delayed secondary phase which is characterized by inflammation activation, vascular disruption, ischemia, oxidative stress, and excitotoxicity [5-6]. The secondary phase is divided into the immediate, acute, intermediate, and chronic stages of SCl [5]. The main features of chronic $\mathrm{SCl}$ are glial scar and cavity formation following function loss [7-8].

Stem cell transplantation has become a widely accepted treatment for overcoming $\mathrm{SCl}$. The first description of mesenchymal stem cells (MSCs) occurred in 1991 [9]. MSCs have gradually become one of the most utilized methods in research and surgery. A number of studies on MSCs transplantation for SCl were conducted [11-16]. The increasing number of the clinical trials employing MSCs for treating SCl indicates that MSCs are considered to be potentially beneficial for translational studies despite several questions which still need to be examined basic and preclinical research level [10].

In order to promote the MSCs transplantation into formal clinical application, the following issues must be addressed, optimal transplantation timing, the most effective transplantation method and the optimal number of stem cells. Our previous research focused on the benefits of employing mesenchymal stem cells in the acute and subacute phase of the contusion rat model [17]. After a broad literature review, we found that the chronic phase could also be considered a potential time to perform cell transplantation [11-16]. Two main reasons are given: (1) globally, there are many chronic $\mathrm{SCl}$ patients eagerly waiting for an effective treatment; (2) the microenvironment is continuously changing during the acute/subacute phase, while it is relatively stable during the chronic stage, which will affect the survival or differentiation of transplanted cells. Considering the transplanted cell survival, migration and safety, intralesional transplantation is preferable, compared with intrathecal transplantation and intravenous transplantation [18-19]. Across the current studies and clinical trials, the number of employed MSCs are not uniform. The number of cells used ranged from $4 \cdot 10^{5}$ to $1 \cdot 10^{6}$ in the animal studies [19-22], and $7 \cdot 10^{5}$ to $2 \cdot 10^{7}$ in the clinical trials $[12,14,15,23]$.

This experiment was designed to determine: (1) to verify our strategy for MSCs precise transplantation; (2) to explore the best number of MSCs transplantation ranged from $4 \cdot 10^{5}$ to $1 \cdot 10^{6}$ for improvement of chronic SCl.

\section{METHODS}

\section{Nanoparticles transplantation}

Nanoparticles were designed and generated as we reported [24]. Transplantation was performed under the guidance of $\mathrm{MRI}$, as we previously reported [25]. Generally, the rats were anesthetized throughout the whole procedure with the $\mathrm{E}-\mathrm{Z}$ Anesthesia system EZ-7000 330 (PA, USA). The fur over T10 was carefully shaved and the exposed skin was sterilize. The skin and the superfcial fascia were opened along the initial laminectomy incision. Two silver acupuncture needles (Kazan medical instruments plant JSC; Russia) were inserted through the erector spinae. The needles were positioned parallel to the ground and at a 40-degree angle to the spine with 1 needle on both sides of the animal. The tips the needles were passed through the muscle and intersected each other, creating a cross-like shape.

The MRI was conducted to calculate both the volume of PTS and the 3-dimensionl (3D) coordinates using the crossed needles as a reference point. Both the lateral and the longitudinal distances between PTS and the crossed needles were measured with software MultiVox Dicom Viewer (R3.0 SP13; USA). The depth of PTS was also calculated.

\section{Animals group allocation}

In order to prove the precise intra-PTS transplantation strategy, adult Sprague-Dawley rats $(n=3)$ weighted 180-220 g were used to create the chronic SCl models. To evaluate the effect of MSCs transplantation, another adult Sprague-Dawley rats $(n=24)$ weighted 180-220 g were used to create the chronic $\mathrm{SCl}$ models. Rats were randomly divided into four groups with 6 rats in each group): (1) DMEM group (the cell culture medium group); (2) the $4 \cdot 10^{5}$ cells group; (3) the $8 \cdot 10^{5}$ cells group; (4) the $1 \cdot 10^{6}$ cells group.

Experiments were carried out in compliance with the principles of International Laboratory Animal Care, and the European Communities Council Directive of 24 November 1986 (86/609/EEC). All efforts were made to minimize the number of animals used and their suffering.

\section{Isolation, Culture, and Characterization of MSCs}

MSCs were collected from the bone marrow of 4-6-monthold SD rats. Generally, in a ficoll density gradient $1.077 \mathrm{~g} / \mathrm{ml}$ (Sigma-Aldrich; USA), we centrifuged to isolate the fraction of mononuclear cells (300 rpm, $30 \mathrm{~min}$ ). The cells were cultured in RPMI 1640 (Gibco; USA), supplemented with 2 mM glutamine, $100 \mathrm{U} / \mathrm{ml}$ penicillin, $0.1 \mathrm{mg} / \mathrm{ml}$ streptomycin (Gibco; USA) and $15 \%$ FBS (Biowest; USA) at $37^{\circ} \mathrm{C}, 5 \% \mathrm{CO}_{2}$. Passage 2-4 MSCs were used in the present research. The presence of positive specific MSCs markers (CD105, CD90, and CD44) and negative hematopoietic markers (CD45, CD34) was verified by flow cytometry (MoFlo sorter; Beckman Coulter; USA) with the appropriate primary-labeled antibodies (Miltenyi Biotec GmbH; Germany).

MSC cells were trypsinized (trypsin-EDTA, 0.25\%) (Invitrogen; Russia) and counted. Then 4 aliquots of medium with the composition of serum free DMEM (Gibco; USA), supplemented with $2 \mathrm{mM}$ glutamine, $100 \mathrm{U} / \mathrm{ml}$ penicillin, $0.1 \mathrm{mg} / \mathrm{ml}$ streptomycin (Gibco; USA) were prepared. Three of them were randomly selected to prepare the cell suspension in different concentrations: $1 \cdot 10^{5}, 2 \cdot 10^{5}$ and $2.5 \cdot 10^{5} \mathrm{cells} / \mu \mathrm{l}$.

\section{Chronic spinal cord injury model}

The surgery was performed as we previously reported [17]. After intraperitoneal anesthetization with ketamine $(50 \mathrm{mg} / \mathrm{kg})$, animals were placed on a warm pad in the prone position and the dorsal fur was shaved. The surgical area was sterilized. The laminectomy at T9-10 segment was performed to expose the spinal cord. Then a force of 200 kilodynes was induced an impact injury to the spinal cord using the PSI-IH Impactor, which has sensors to accurately measure the impact force. (Precision Systems and Instrumentation LLC, Fairfax, VA; USA). 
After flushing the wound with ice saline, the surgical site was sutured. A subcutaneous injection of Baytril $(2.5 \mathrm{mg} / \mathrm{kg} / \mathrm{d})$ (Bayer; USA) was administered on the rats. After surgery, the animals were returned to their home cages and received manual bladder expression twice daily until the recovery of spontaneous urinary function.

\section{Stereotactic MSCs transplantation}

Cell transplantation was performed at $4 \mathrm{w}$ post injury [11]. After the induction of general anesthesia, the cell transplantation was performed through the skin guided by MRI. MRI was employed to locate the injured area of each rat prior to the transplantation procedure. Using a Hamilton syringe and a 33gauge, 45 degree-beveled needle (Hamilton, Reno; USA), $4 \mu$ of liquid was directly transplanted into the injury area with the assistance of the microinjection unit and Razel Syringe Pump (NE-1002X) (Razel Scientific; USA) in 2 min. The needle was held at the injection site for 2 min and was withdrawn slowly for another minute.

\section{MRI and DTI scan}

All rats were anesthetized throughout the whole procedure by inhalation of isoflurane (5DG9621, BAXTER; USA) with the E-Z Anesthesia system (EZ-7000 330, PA; USA). MRI and DTI scans were performed using 7 Tesla animal MRI scanners (ClinScan, Bruker BioSpin; USA) on the first and the fourth week after $\mathrm{SCl}$ to evaluate the injury area, and the eighth week after $\mathrm{SCl}$ to determine the effect of MSCs transplantation. For coronal images: T2-weighted images in coronal plane were acquired by Turbo Spin Echo sequence with the following parameters: FOV $120 \cdot 59.2 \mathrm{~mm}$, base resolution $320 \cdot 158, \mathrm{TR}=3850 \mathrm{~ms}$, $\mathrm{TE}=39 \mathrm{~ms}$, slice thickness $1 \mathrm{~mm}$, number of acquisition $=1$, echo train length $=9$. For sagittal images: T2-weighted imaged in sagittal plane were acquired by Turbo Spin Echo sequence with following parameters: FOV $100 \cdot 49.2 \mathrm{~mm}$, base resolution 256 $126, \mathrm{TR}=3850 \mathrm{~ms}, \mathrm{TE}=42 \mathrm{~ms}$, slice thickness $1 \mathrm{~mm}$, number of acquisition $=3$, echo train length $=9$.

DTI images were acquired with identical geometry as the anatomical images using single shot spin-echo planar imaging (EPI) sequence with TR/TE of $4000 \mathrm{~ms} / 88 \mathrm{~ms}$, slice thickness of $3 \mathrm{~mm}$, b factor of $1000 \mathrm{~s} / \mathrm{mm} 2$, bandwidth of $200 \mathrm{kHz}, 25$ gradient encoding directions, acquisition matrix of $64 \cdot 64$, and field of view $10 \cdot 10 \mathrm{~mm}$. To calculate the DTI indices, the collected images were analyzed on an independent workstation. DTT of the spinal cord was generated using the FACT algorithm implemented in Volume-One software, and fractional anisotropy (FA) threshold $<0.2$ and stopping angle of $>25^{\circ}$ were used as parameters.

\section{Macroscopic assessment of injury area}

Macroscopic assessment was performed $8 \mathrm{w}$ post cell transplantation in each rat. All rats were humanely euthanized with the same aforementioned process. Intracardial perfusion with saline and then $4 \%$ paraformaldehyde was performed to flush possible blood components from the sample. The spinal cords form the injury level were collected. The images of spinal cords from each group were generated by the digital camera (Leica Co.; Germany). With Image J software (Basics 1.38; USA), the macroscopic injury sites on the surface of spinal cords were selected and the injury areas were autocalculated. The average injury area of each group was gained and quantitatively compared.

\section{Hematoxylin-eosin (H \& E) staining}

After macroscopic assessment, rats were deeply anesthetized with ketamine and xylazine, and perfused with saline and $4 \%$ paraformaldehyde in $0.1 \mathrm{M}$ phosphate buffer. Three spinal cord samples from each group were randomly selected. The samples were dehydrated gradually in 70\%, 80\%, 90\%, 100\% ethanol, and embedded in xylene and paraffin. $10 \mu \mathrm{m}$ longitudinal slices were made on the microtome (Rotary microtome) (Microm HM 650V; USA).

For hematoxylin eosin staining, slices were hydrated in $100 \%, 90 \%, 80 \%, 70 \%$ ethanol and water, stained in hematoxylin for 1 minute, washed in water for 5 minutes, followed by staining in eosin for 1 minute. After coversliping with entelan, the slices were sent to the light microscope for the evaluation of the injured area. Three slices from each group were collected, the mean injured area was calculated. With Image $\mathrm{J}$ software, the injury sites of the slices were selected and the injury areas were auto-calculated. The average injury area of each group was gained and quantitatively compared.

\section{Immunohistochemistry (IHC)}

Three spinal cords from each group were randomly selected. The samples were embedded in PBS, 50 $\mu \mathrm{m}$ longitudinal slices were made on the vibratome HM 650V (Thermo Scientific; USA). Three slices from each sample were collected and analyzed. The slices were incubated with anti-microtubule Associated Protein 2 (MAP2; mouse anti-rat; $1: 400$ ) (Abcam;

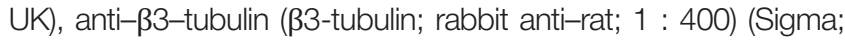
USA), anti-glial fibrillary acidic protein (GFAP; rabbit anti-rat; $1: 500$ ) (Abcam; UK), Nestin (1: 400, rabbit anti-rat) (Abcam; UK), brain derived neurotrophic factor (BDNF; mouse anti-rat; 1 : 400) (Abcam; UK) and vascular ecndothelial growth factor (VEGF; mouse anti-rat; 1 : 200) (Abcam; UK) overnight at $4{ }^{\circ} \mathrm{C}$, followed by TRITC-conjugated goat anti-mouse or FITCconjugated anti-rabbit lgG (1 : 200; ZSGB-BIO) for one hour at $37^{\circ} \mathrm{C}$. The slices were examined using confocal microscopy (Nikon, A1+MP) (Nikon; Japan).

3D surface plot was employed for evaluating fluorescence measurements semi-quantitatively. The sample's heatmap of each slice was generated based on the fluorescence intensity in different fluorescence channels. The sample's heatmap, which is simply a three-column matrix colored from light blue to bright red, illustrated the different expressional levels of positive proteins.

\section{Behavioral analysis}

Basso, Beattie, and Bresnahan (BBB) locomotor test was performed based on the principle of double blind before injury and weekly post injury to evaluate the hindlimb motor behavior recovery. To assess motor coordination, a rotarod test was conducted before the rats were killed (at $8 \mathrm{w}$ post transplantation). All rats were placed on a standard Rotarod (Med Associates, Inc.; USA) to determine their motor performances. The test was not conducted throughout all the experimental period because falling from the rod might lead to further injuries. Each animal was placed on a $10 \mathrm{~cm}$ diameter, $15 \mathrm{~cm}$ long rod, rotating at constant speed. Impairment of motor coordination was defined as the inability of rats to remain on the rotating rod for a $60 \mathrm{~s}$ test period. Animals were pretrained on the rotating track before the injury and re-trained $24 \mathrm{~h}$ before the test. The testing protocol comprised of one $60 \mathrm{~s}$ test period every 24 hours for 72 hours. On these continuous 
days of testing at 4,8 , and 12 rpm on, respectively, $1^{\text {st }}, 2^{\text {nd }}$, and $3^{\text {rd }}$ day, with a 10 min interval between each trial.

\section{Statistical analysis}

All statistical analyses were performed by SPSS 17.0 software package (SPSS Inc.; USA). Results were considered to be statistically significant with $p<0.05$. All data are presented as mean \pm standard error of the mean (SEM), and repeated measures ANOVA (RANOVA) was employed.

\section{RESULTS}

\section{Precise transplantation into PTS}

The nanoparticles showed low signal change in T2-weighted MRI scanning (Fig. 1). Nanoparticle transplantation was repeatedly conducted in the rats with PTS. As shown in Figure, the PTS volume showed a significant decrease from (5.71 \pm $0.21) \mathrm{mm}^{3}$ to $(3.23 \pm 0.364) \mathrm{mm}^{3}$ post first transplantation $(p<0.05)$, the volume further decreased from $(3.23 \pm 0.364)$ $\mathrm{mm}^{3}$ to $(1.48 \pm 0.722) \mathrm{mm}^{3}$ post sect transplantation $(p<0.05)$. Thus, our transplantation strategy was proved to be precise by nanoparticle.

\section{General situation and motor functional recovery}

All the rats involved in the present research showed no signs of complications or died unexpectedly, during the whole experimental procedure.

Preoperatively, the rat BBB scores were 21 points in all rats. Immediately after $\mathrm{SCl}$, all rats demonstrated significant loss of motor function of the hind limbs and the BBB scores were reduced to 0 points (Fig. 2). Gradually, BBB score increased in all groups, and reached $5.85 \pm 0.83$ (DMEM group), $5.94 \pm 0.74$ (4 $\cdot 10^{5}$ group), $6.08 \pm 0.75$ ( $8 \cdot 10^{5}$ group) and $6.02 \pm 0.84$ $\left(1 \cdot 10^{6}\right.$ group) at four weeks after injury. Differences in the BBB scores among the four groups were not statistically significant before cell transplantation.

One week post transplantation, compared with the DMEM group, the differences were found to be statistically significant in cell transplanted groups (Fig. 2M). Compared with the
DMEM group, the behavior ability also suggested the better outcome in the cell transplanted groups. Among all the groups, $1 \cdot 10^{6}$ group showed the best outcome (Fig. 2M). Eight-week post transplantation, BBB score reached $7.02 \pm 1.36$ (DMEM group), $8.14 \pm 1.12$ ( $4 \cdot 10^{5}$ group), $10.25 \pm 1.02$ ( $8 \cdot 10^{5}$ group) and $11.07 \pm 1.44\left(1 \cdot 10^{6}\right.$ group). The rats showed different behavior abilities on weight support, plantar placement, and plantar stepping (Fig. 2A-M).

\section{The Reduction of PTS}

MRI was performed on the first week and fourth week post injury, and eighth week post MSCs transplantation. The formation of post-traumatic syrinx (PTS) was evaluated. As shown in the Table 1, the cases of the animal with PTS on different weeks were listed.

As shown in the Fig. 4, the PTS volumes were calculated based on the MRI. The volume of PTS decreased in the cell transplant groups when evaluated $8 \mathrm{w}$ post transplantation. Among all the groups, $1.10^{6}$ group showed the best improvement (Fig. 3S-Y).

The visible injured area was caluated in order to evaluate the effect of MSCs on preventing scar formation post chronic SCl. As shown in the Figure 4, compared with the DMEM group, the differences were statistically significant in cell transplanted groups (Fig. 4E). Among all the groups, $1 \cdot 10^{6}$ group showed the best outcome (Fig. 4A-E).

\section{The promotion of neural restoration}

In order to evaluate the effect of MSCs on promoting the neural regeneration and sprouting, DTI and DTT were conducted on eighth week post cell transplantation. As shown in the Fig. 4 and Table 2, the dorsal columns tracts of lesion site from each group were evaluated. Compared with the DMEM group, the continuity and density of neural fibers were found to be improved in cell transplanted groups (Fig. 4B-D). Among all the groups, $1 \cdot 10^{6}$ group showed the best neural fibers with complete continuity and high density (Fig. 4D). As shown in the Table 2, compared with other groups, ADC showed significant decrease and FA showed significant increase in the $1.10^{6}$ MSCs group, the effect showed the cell-dose dependent manner.
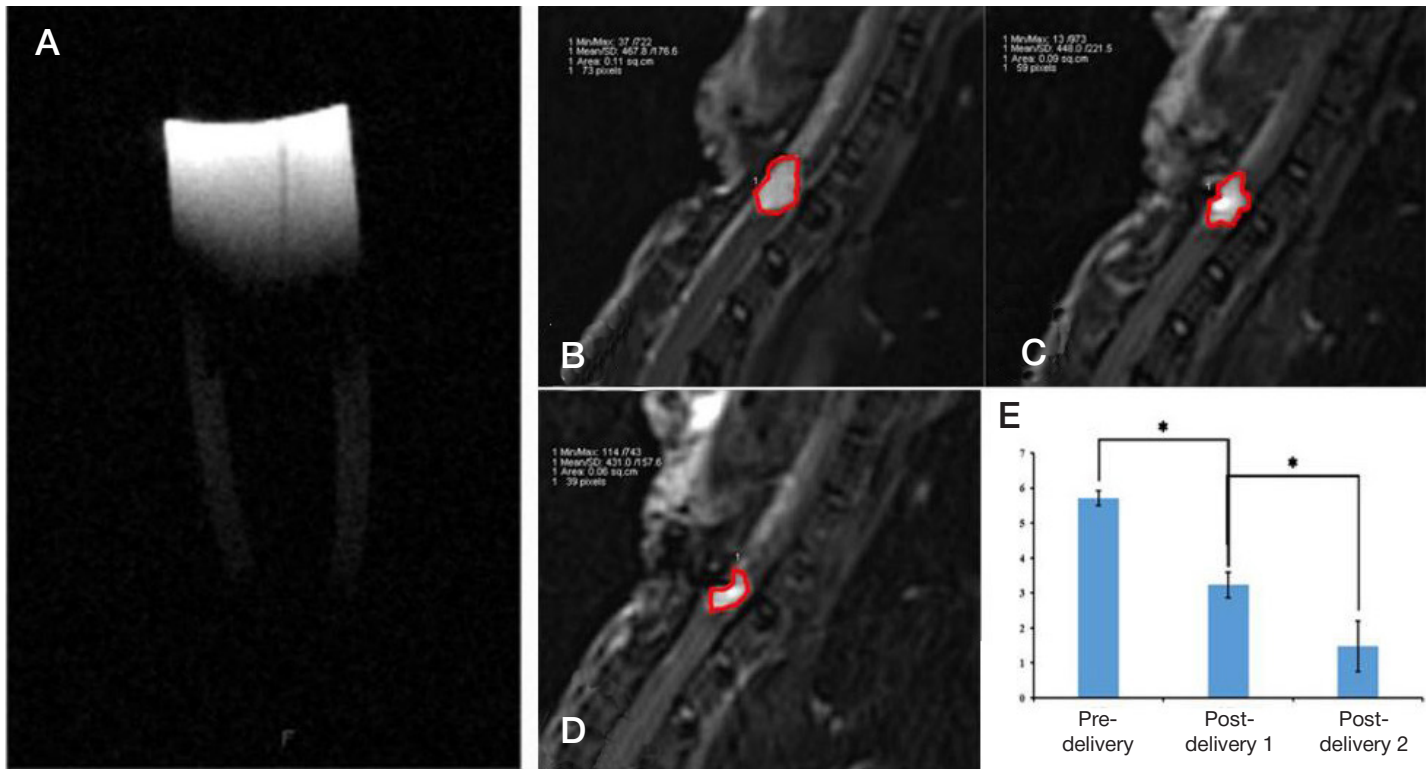

Fig. 1. Nanoparticles transplantation and MRI analysis. A. Nanoparticles showed low signal change in T2-weighted scanning. B-E. The volume change of PTS post nanoparticle transplantation. PTS volume decreased after the first transplantation, and further decreased after the second transplantation $(p<0.05)$ 


\section{DISCUSSION}

Based on the present research and the previous reports, it was suggested that the beneficial effect of MSCs transplantation is dose-dependent [26]. The research into the optimal dose is desirable. The optimize number of cells ranged from $4 \cdot 10^{5}$ to $1 \cdot 10^{6}$ was studied in the present research. In order to avoid producing additional damage to the spinal cord, high concentrations of cells were employed. In the present research, $1 \cdot 10^{5}, 2 \cdot 10^{5}$ and $2.5 \cdot 10^{5}$ cells/ $\mu$ l were employed [19-22]. As observed, $2.5 \cdot 10^{5}$ cells/ $\mu$ is the maximum concentration for preparing MSCs. The higher concentration exerted the negative influences on cells survival, and required the larger caliber of the injection needle, which led to additional damage. The smallest possible volume $4 \mu$ of cell suspension was used due to the volume of the rat spinal cord and the adequate cell suspension medium for cells survival [19-22].

Varying strategies for transplantation into the spinal cord were reported, including lesion site delivery, single-point with various intervals delivery, multi-target point delivery, and twice
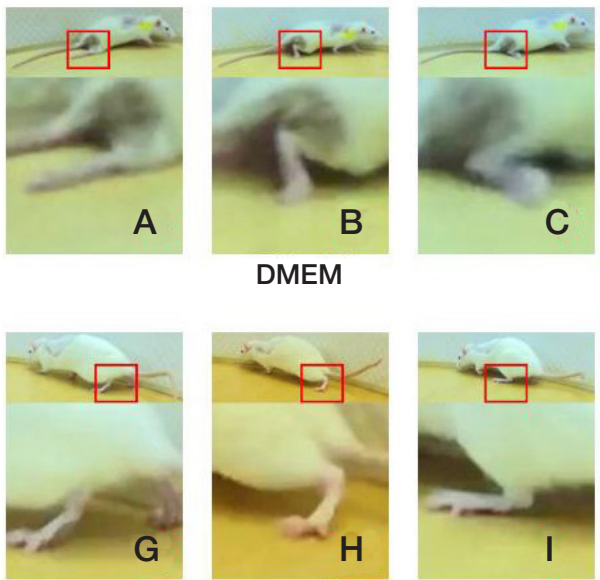

$8 \cdot 10^{2}$ separately delivery [26-28]. Four factors should be considered when planning an administration route: (1) a greater number of cells could be administered into lesion site and fewer cells could be administered into normal tissue; (2) higher rates of cell survival; (3) the approach that can be repeated accurately in each individual; (4) less added damage. Thus, based on our previous reports, the local lesion site delivery was employed in the present research [25].

Several studies reported that MSCs transplantation was able to positively improve the outcome post SCI [19-22]. Based on the present study, MSCs transplantation can stimulate the regeneration and sprouting of the axons, improve the motor function recovery, reduce the formation of PTS and glial scar, promote vascularization and neuro-trophic factor expression. In the present research, the effect suggested the cell numberdependent manner, 1 - $10^{6}$ cells showed the best outcome among all groups. The hypothesis can be drawn that the more employed cells, the better gained effect. It was reported that one of the main mechanisms of MSCs transplantation on treating chronic SCI is MSCs' paracrine effect [11]. Thus,
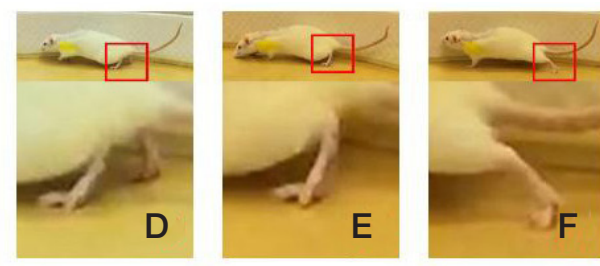

$4 \cdot 10^{5}$
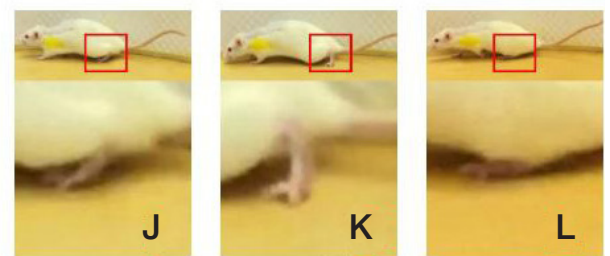

$1 \cdot 10^{6}$

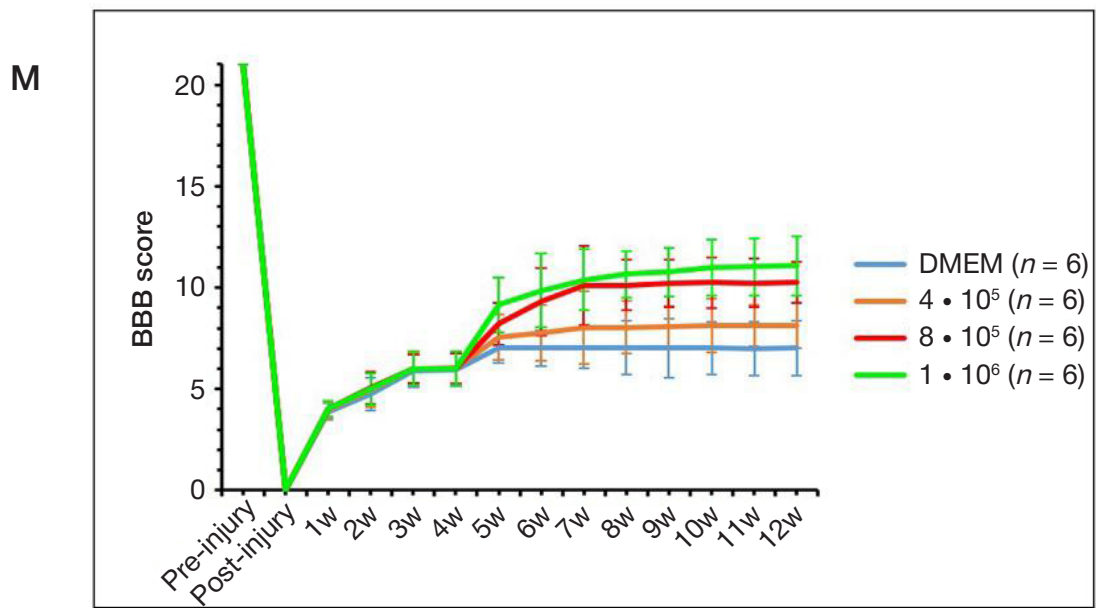

Fig. 2. Motor function recovery evaluated by BBB score. Differences in the BBB scores among the four groups were not statistically significant before cell transplantation. One-week post transplantation, compared with the DMEM group, the differences were found to be statistically significant in cell transplanted groups (M). Compared with the DMEM group, the behavior ability suggested the better outcome in the cell transplanted groups. Among all the groups, $1 \cdot 10^{6}$ group showed the best outcome (M). Eight-week post transplantation, the rats showed different abilities on weight support (A, D, G, J), plantar placement (B, E, H, K), and plantar stepping (C, F, I, L)

Table 1. The cases counting of PTS formation

\begin{tabular}{|c|c|c|c|}
\hline & 1 w post injury & 4 w post injury & 8 w post transplantation \\
\hline DMEM group & 0 & 3 & 3 \\
\hline $4 \cdot 10^{5}$ group & 0 & 3 & 3 \\
\hline $8 \cdot 10^{5}$ group & 0 & 4 & 4 \\
\hline $1 \cdot 10^{6}$ group & 0 & 4 & 3 \\
\hline
\end{tabular}



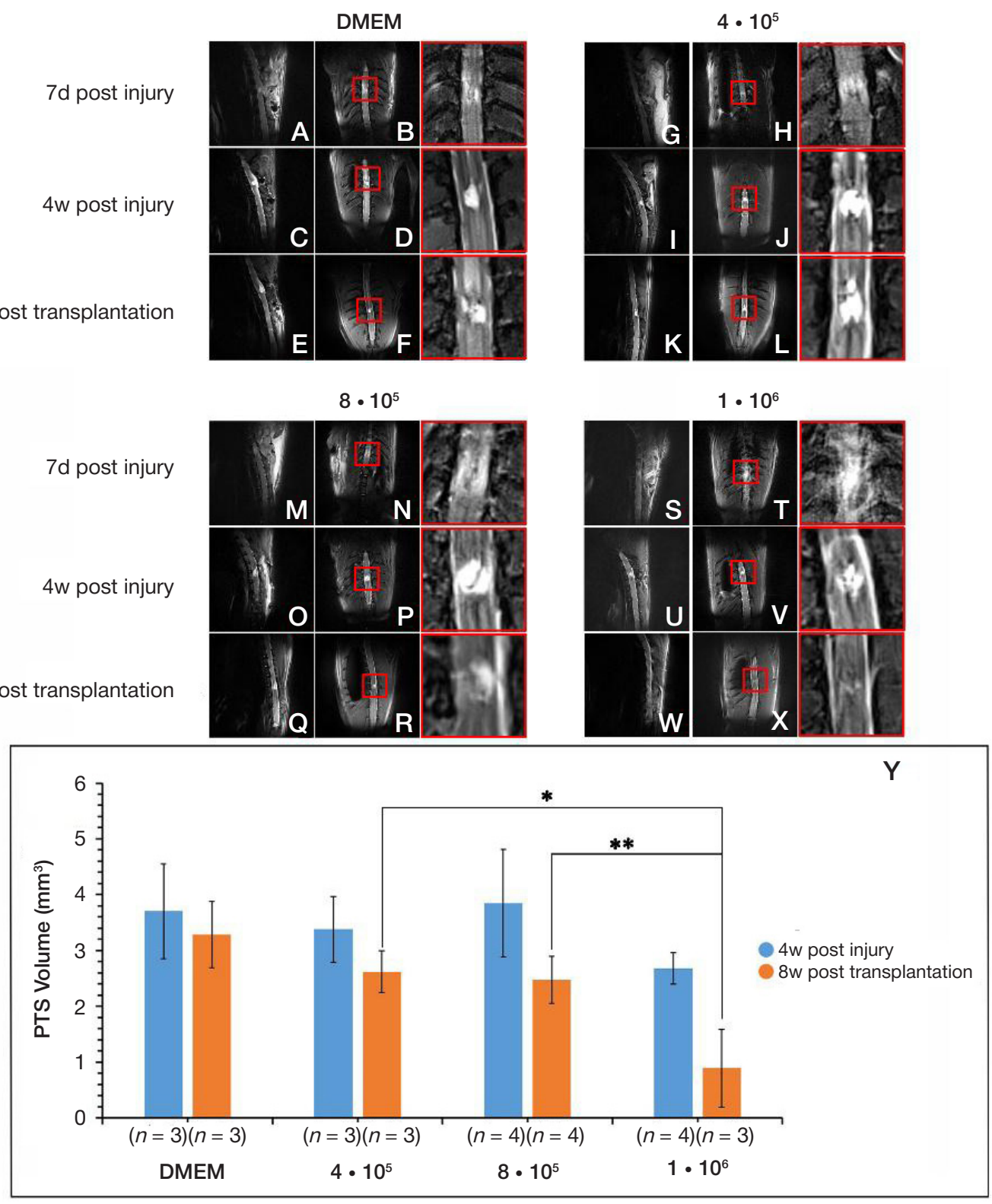

Fig. 3. The Reduction of post-traumatic syrinx. Lateral and horizontal MRI scanning was performed in all groups to evaluate the situation of post-traumatic syrinx preand post- transplantation $(\mathbf{A}-\mathbf{X})$. The volume of PTS decreased in the cell transplant groups when evaluated 8 w post transplantation. Among all the groups, 1 • $10^{6}$ group showed the best improvement $(\mathbf{S}-\mathbf{Y})$. The areas in the red box were magnified in the figures with red frame

DMEM
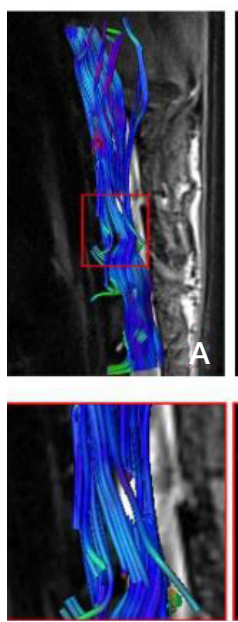

$4 \cdot 10^{5}$
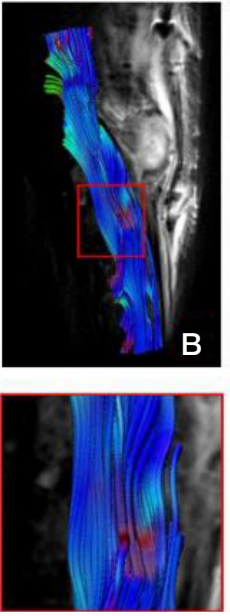

$8 \cdot 10^{5}$
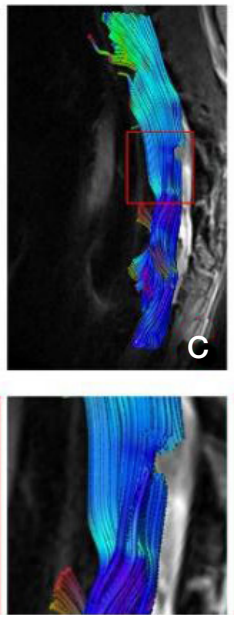

$1 \cdot 10^{6}$
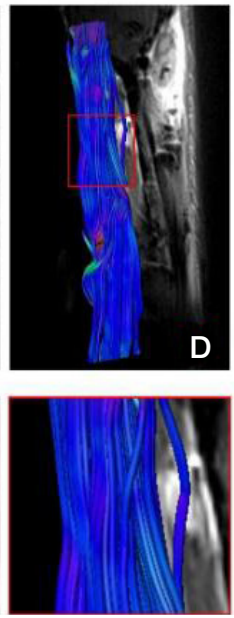

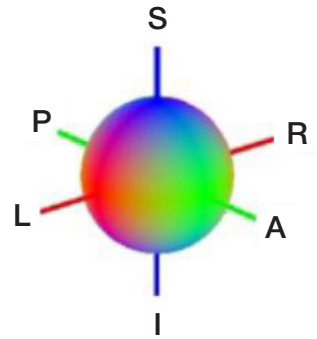

Colour instruction:

Blue: inferior-superior direction

Red: left-right direction

Green: anterior-posterior direction

Fig. 4. Tractography images of the spinal cords in all the groups at $8 \mathrm{w}$ post cell transplantation. Tractography image of the spinal cord in DMEM group showed the fracture of neural fibers (A). All cell transplanted groups showed the repairing sign of spinal neural fibers (B-D). $1 \cdot 10^{6}$ group showed the best outcome (D) 
Table 2. The situation of $A D C$ and $F A$ in the injury area

\begin{tabular}{|c|c|c|c|c|c|c|c|c|}
\hline \multirow{2}{*}{ Group } & \multicolumn{2}{|c|}{ DMEM } & \multicolumn{2}{|c|}{$4 \cdot 10^{5} \mathrm{MSCs}$} & \multicolumn{2}{|c|}{$8 \cdot 10^{5} \mathrm{MSCs}$} & \multicolumn{2}{|c|}{$1 \cdot 10^{6} \mathrm{MSCs}$} \\
\hline & ADC & $\mathrm{FA}$ & ADC & FA & ADC & FA & ADC & FA \\
\hline $\begin{array}{c}\text { 8w post } \\
\text { transplantation }\end{array}$ & $\begin{array}{c}(1792.64 \pm 719.28) \\
\cdot 10^{-6} \mathrm{~mm}^{2} / \mathrm{s}\end{array}$ & $0.34 \pm 0.08$ & $\begin{array}{c}(1483.52 \pm 924.91) \\
\cdot 10^{-6} \mathrm{~mm}^{2} / \mathrm{s}\end{array}$ & $0.41 \pm 0.10$ & $\begin{array}{c}(1351.77 \pm 1024.55) \\
\cdot 10^{-6} \mathrm{~mm}^{2} / \mathrm{s}\end{array}$ & $0.45 \pm 0.09$ & $\begin{array}{c}(1276.39 \pm 1214.84) \\
\cdot 10^{-6} \mathrm{~mm}^{2} / \mathrm{s}\end{array}$ & $0.51 \pm 0.12$ \\
\hline
\end{tabular}

we hypothesized that the more employed cells, the more gained trophic factors. As proved in the present research with immunohistochemistry, the expressional levels of BDNF and VEGF in the lesion site were the highest after the transplantation of $1 \cdot 10^{6}$ cells among all groups, while after transplanting $4 \cdot 10^{5}$ cells and $8 \cdot 10^{5}$ cells, the BDNF and VEGF expressions were also improved compared with DMEM group. Currently, there has been no quantitative study looking into the changing of trophic factors post chronic SCl, or looking into the detailed number of desired trophic factors for treating SCl. Our study suggested the more employed cells, the higher expressional trophic factors, the better gained behavioral recovery. However, prudent planning should be employed when increasing cell volume and/or concentration to ensure additional damage.

It is a limitation of the present research that the survival rates of the transplanted MSCs were not evaluated. Further studies on the evaluation of survival rates and cell apoptosis would be performed.

\section{CONCLUSIONS}

MSCs transplantation therapy for chronic $\mathrm{SCl}$ is a safe strategy with the concentration of $1 \cdot 10^{5}, 2 \cdot 10^{5}$ and $2.5 \cdot 10^{5} \mathrm{cells} / \mathrm{\mu l}$, and with the cells number of $4 \cdot 10^{5}, 8 \cdot 10^{5}$, and $1 \cdot 10^{6}$. In the present basic study in vivo, MSCs can restore function after chronic SCl through stimulating the regeneration and sprouting of the axons, improving the motor function recovery, reducing the formation of PTS and glial scar, promoting vascularization and neuro-trophic factor expression. The effect was cell number-dependent, and $1 \cdot 10^{6}$ cells were proved to be the best dose. At the same time, the combined application of DTI and DTT could be the quantitative strategy for evaluating PTS situation post chronic SCl.

\section{References}

1. Ning GZ, Yu TQ, Feng SQ, Zhou XH, Ban DX, Liu $Y$ et al Epidemiology of traumatic spinal cord injury in Tianjin, China. Spinal Cord. 2011; (49): 386-90.

2. Furlan JC, Sakakibara BM, Miller WC, Krassioukov AV. Global incidence and prevalence of traumatic spinal cord injury. Can $J$ Neurol Sci. 2014; (40): 456-64.

3. Oliveri RS, Bello S, Biering-Sørensen F. Mesenchymal stem cells improve locomotor recovery in traumatic spinal cord injury: systematic review with meta-analyses of rat models. Neurobiol Dis. 2014; (62): 338-53.

4. Devivo M. Epidemiology of traumatic spinal cord injury: Trends and future implications. Spinal Cord. 2012; (50): 365-72.

5. Siddiqui AM, Khazaei M, Fehlings MG. Translating mechanisms of neuroprotection, regeneration, and repair to treatment of spinal cord injury. Prog Brain Res. 2015; (218): 15-54.

6. Salewski RP, Mitchell RA, Li L, Shen C, Milekovskaia M, Nagy A et al. Transplantation of Induced Pluripotent Stem Cell-Derived Neural Stem Cells Mediate Functional Recovery Following Thoracic Spinal Cord Injury Through Remyelination of Axons. Stem Cells Transl Med. 2015; (4): 743-54.

7. Raspa A, Pugliese R, Maleki M, Gelain F. Recent therapeutic approaches for spinal cord injury. Biotechnol Bioeng. 2016; (113): 253-9.

8. Boido M, Garbossa D, Fontanella M, Ducati A, Vercelli A Mesenchymal stem cell transplantation reduces glial cyst and improves functional outcome after spinal cord compression. World Neurosurg. 2014; (81): 183-90.

9. Caplan Al. Mesenchymal stem cells. J Orthop Res. 1991; (9): 641-50

10. U.S. National Institutes of Health. Clinical trials. Available from: https://clinicaltrials.gov/.

11. de Almeida FM, Marques SA, Ramalho Bdos S, Massoto TB, Martinez AM. Chronic spinal cord lesions respond positively to tranplants of mesenchymal stem cells. Restor Neurol Neurosci. 2015; (33): 43-55.

12. Mendonça MV, Larocca TF, de Freitas Souza BS, Villarreal CF, Silva LF, Matos AC et al. Safety and neurological assessments after autologous transplantation of bone marrow mesenchymal stem cells in subjects with chronic spinal cord injury. Stem Cell Res Ther. 2014; (5): 126.

13. Lee SH, Kim Y, Rhew D, Kuk M, Kim M, Kim WH et al. Effect of the combination of mesenchymal stromal cells and chondroitinase ABC on chronic spinal cord injury. Cytotherapy. 2015; (17): 1374-83.
14. Amr SM, Gouda A, Koptan WT, Galal AA, Abdel-Fattah DS, Rashed LA et al. Bridging defects in chronic spinal cord injury using peripheral nerve grafts combined with a chitosan-laminin scaffold and enhancing regeneration through them by cotransplantation with bone-marrow-derived mesenchymal stem cells: case series of 14 patients. J Spinal Cord Med. 2014; (37): 54-71.

15. Dai G, Liu X, Zhang Z, Yang Z, Dai $Y, X u$ R. Transplantation of autologous bone marrow mesenchymal stem cells in the treatment of complete and chronic cervical spinal cord injury. Brain Res. 2013; (1533): 73-9.

16. Hodgetts SI, Simmons PJ, Plant GW. A comparison of the behavioral and anatomical outcomes in sub-acute and chronic spinal cord injury models following treatment with human mesenchymal precursor cell transplantation and recombinant decorin. Exp Neurol. 2013; (248): 343-9.

17. Ning G, Tang L, Wu Q, Li Y, Li Y, Zhang $C$ et al. Human umbilical cord blood stem cells for spinal cord injury: early transplantation results in better local angiogenesis. Regen Med. 2013; (8): 271-81.

18. Takahashi Y, Tsuij O, Kumagai G, Hara CM, Okano HJ, Miyawaki A et al. Comparative study of methods for administering neural stem/ progenitor cells to treat spinal cord injury in mice. Cell Transplant. 2011; (20): 727-39.

19. Kim JW, Ha KY, Molon JN, Kim YH. Bone marrow-derived mesenchymal stem cell transplantation for chronic spinal cord injury in rats: comparative study between intralesional and intravenous transplantation. Spine (Phila Pa 1976). 2013; (38): E1065-74.

20. Amemori T, Jendelová P, Růzicková K, Arboleda D, Syková E. Cotransplantation of olfactory ensheathing glia and mesenchymal stromal cells does not have synergistic effects after spinal cord injury in the rat. Cytotherapy. 2010; (12): 212-25.

21. Kang KN, Kim DY, Yoon SM, Lee JY, Lee BN, Kwon JS et al. Tissue engineered regeneration of completely transected spinal cord using human mesenchymal stem cells. Biomaterials. 2012; (33): 4828-35.

22. Kumagai G, Tsoulfas P, Toh S, McNiece I, Bramlett HM, Dietrich WD. Genetically modified mesenchymal stem cells (MSCs) promote axonal regeneration and prevent hypersensitivity after spinal cord injury. Exp Neurol. 2013; (248): 369-80.

23. Karamouzian S, Nematollahi-Mahani SN, Nakhaee N, Eskandary H. Clinical safety and primary efficacy of bone marrow mesenchymal 
cell transplantation in subacute spinal cord injured patients. Clin Neurol Neurosurg. 2012; (114): 935-9.

24. Abakumov MA, Nukolova NV, Sokolsky-Papkov M, et al. VEGFtargeted magnetic nanoparticles for MRI visualization of brain tumor. Nanomedicine. 2015; 11 (4): 825-33.

25. Zhang C, Morozova AY, Abakumov MA, Gubsky IL, Douglas P, Feng $S$ et al. Precise Delivery Into Chronic Spinal Cord Injury Syringomyelic Cysts with Magnetic Nanoparticles MRI Visualization. Med Sci Monit. 2015; (21): 3179-85.

26. Cigognini D, Satta $A$, Colleoni B, Silva D, Donegà M, Antonini S et al. Evaluation of early and late effects into the acute spinal cord injury of an injectable functionalized self-assembling scaffold. PLoS One. 2011; (6): e1978.

27. Mannoji C, Koda M, Kamiya K, Dezawa M, Hashimoto M, Furuya T et al. Transplantation of human bone marrow stromal cell-derived neuroregenrative cells promotes functional recovery after spina cord injury in mice. Acta Neurobiol Exp (Wars). 2014; (74): 479-88.

28. Rao YJ, Zhu WX, Du ZQ, Jia CX, Du TX, Zhao QA et al. Effectiveness of olfactory ensheathing cell transplantation for treatment of spinal cord injury. Genet Mol Res. 2014; (13): 4124-9.

\section{Литература}

1. Ning GZ, Yu TQ, Feng SQ, Zhou XH, Ban DX, Liu Y et al. Epidemiology of traumatic spinal cord injury in Tianjin, China. Spinal Cord. 2011; (49): 386-90.

2. Furlan JC, Sakakibara BM, Miller WC, Krassioukov AV. Globa incidence and prevalence of traumatic spinal cord injury. Can $J$ Neurol Sci. 2014; (40): 456-64.

3. Oliveri RS, Bello S, Biering-Sørensen F. Mesenchymal stem cells improve locomotor recovery in traumatic spinal cord injury: systematic review with meta-analyses of rat models. Neurobio Dis. 2014; (62): 338-53.

4. Devivo M. Epidemiology of traumatic spinal cord injury: Trends and future implications. Spinal Cord. 2012; (50): 365-72.

5. Siddiqui AM, Khazaei M, Fehlings MG. Translating mechanisms of neuroprotection, regeneration, and repair to treatment of spinal cord injury. Prog Brain Res. 2015; (218): 15-54

6. Salewski RP, Mitchell RA, Li L, Shen C, Milekovskaia M, Nagy A et al. Transplantation of Induced Pluripotent Stem Cell-Derived Neural Stem Cells Mediate Functional Recovery Following Thoracic Spinal Cord Injury Through Remyelination of Axons. Stem Cells Transl Med. 2015; (4): 743-54.

7. Raspa A, Pugliese R, Maleki M, Gelain F. Recent therapeutic approaches for spinal cord injury. Biotechnol Bioeng. 2016; (113): 253-9.

8. Boido M, Garbossa D, Fontanella M, Ducati A, Vercelli A Mesenchymal stem cell transplantation reduces glial cyst and improves functional outcome after spinal cord compression. World Neurosurg. 2014; (81): 183-90.

9. Caplan Al. Mesenchymal stem cells. J Orthop Res. 1991; (9): 641-50.

10. U.S. National Institutes of Health. Clinical trials. Available from: https://clinicaltrials.gov/.

11. de Almeida FM, Marques SA, Ramalho Bdos S, Massoto TB, Martinez AM. Chronic spinal cord lesions respond positively to tranplants of mesenchymal stem cells. Restor Neurol Neurosci. 2015; (33): 43-55.

12. Mendonça MV, Larocca TF, de Freitas Souza BS, Villarreal CF, Silva LF, Matos AC et al. Safety and neurological assessments after autologous transplantation of bone marrow mesenchymal stem cells in subjects with chronic spinal cord injury. Stem Cell Res Ther. 2014; (5): 126.

13. Lee SH, Kim Y, Rhew D, Kuk M, Kim M, Kim WH et al. Effect of the combination of mesenchymal stromal cells and chondroitinase ABC on chronic spinal cord injury. Cytotherapy. 2015; (17): 1374-83.

14. Amr SM, Gouda A, Koptan WT, Galal AA, Abdel-Fattah DS, Rashed LA et al. Bridging defects in chronic spinal cord injury using peripheral nerve grafts combined with a chitosan-laminin scaffold and enhancing regeneration through them by cotransplantation with bone-marrow-derived mesenchymal stem cells: case series of 14 patients. J Spinal Cord Med. 2014; (37): 54-71.

15. Dai G, Liu X, Zhang Z, Yang Z, Dai Y, Xu R. Transplantation of autologous bone marrow mesenchymal stem cells in the treatment of complete and chronic cervical spinal cord injury. Brain Res. 2013; (1533): 73-9.
16. Hodgetts SI, Simmons PJ, Plant GW. A comparison of the behavioral and anatomical outcomes in sub-acute and chronic spinal cord injury models following treatment with human mesenchymal precursor cell transplantation and recombinant decorin. Exp Neurol. 2013; (248): 343-9.

17. Ning G, Tang L, Wu Q, Li Y, Li Y, Zhang $C$ et al. Human umbilical cord blood stem cells for spinal cord injury: early transplantation results in better local angiogenesis. Regen Med. 2013; (8): 271-81.

18. Takahashi Y, Tsuji O, Kumagai G, Hara CM, Okano HJ, Miyawaki A et al. Comparative study of methods for administering neural stem/ progenitor cells to treat spinal cord injury in mice. Cell Transplant. 2011; (20): 727-39.

19. Kim JW, Ha KY, Molon JN, Kim YH. Bone marrow-derived mesenchymal stem cell transplantation for chronic spinal cord injury in rats: comparative study between intralesional and intravenous transplantation. Spine (Phila Pa 1976). 2013; (38): E1065-74.

20. Amemori T, Jendelová P, Růzicková K, Arboleda D, Syková E. Cotransplantation of olfactory ensheathing glia and mesenchymal stromal cells does not have synergistic effects after spinal cord injury in the rat. Cytotherapy. 2010; (12): 212-25.

21. Kang KN, Kim DY, Yoon SM, Lee JY, Lee BN, Kwon JS et al. Tissue engineered regeneration of completely transected spinal cord using human mesenchymal stem cells. Biomaterials. 2012; (33): 4828-35.

22. Kumagai G, Tsoulfas P, Toh S, McNiece I, Bramlett HM, Dietrich WD. Genetically modified mesenchymal stem cells (MSCs) promote axonal regeneration and prevent hypersensitivity after spinal cord injury. Exp Neurol. 2013; (248): 369-80.

23. Karamouzian S, Nematollahi-Mahani SN, Nakhaee N, Eskandary H. Clinical safety and primary efficacy of bone marrow mesenchymal cell transplantation in subacute spinal cord injured patients. Clin Neurol Neurosurg. 2012; (114): 935-9.

24. Abakumov MA, Nukolova NV, Sokolsky-Papkov M, et al. VEGFtargeted magnetic nanoparticles for MRI visualization of brain tumor. Nanomedicine. 2015; 11 (4): 825-33.

25. Zhang C, Morozova AY, Abakumov MA, Gubsky IL, Douglas P, Feng $S$ et al. Precise Delivery Into Chronic Spinal Cord Injury Syringomyelic Cysts with Magnetic Nanoparticles MRI Visualization. Med Sci Monit. 2015; (21): 3179-85.

26. Cigognini $\mathrm{D}$, Satta $\mathrm{A}$, Colleoni $\mathrm{B}$, Silva $\mathrm{D}$, Donegà $\mathrm{M}$, Antonini $\mathrm{S}$ et al. Evaluation of early and late effects into the acute spinal cord injury of an injectable functionalized self-assembling scaffold. PLoS One. 2011; (6): e1978

27. Mannoji C, Koda M, Kamiya K, Dezawa M, Hashimoto M, Furuya T et al. Transplantation of human bone marrow stromal cell-derived neuroregenrative cells promotes functional recovery after spinal cord injury in mice. Acta Neurobiol Exp (Wars). 2014; (74): 479-88.

28. Rao YJ, Zhu WX, Du ZQ, Jia CX, Du TX, Zhao QA et al. Effectiveness of olfactory ensheathing cell transplantation for treatment of spinal cord injury. Genet Mol Res. 2014; (13): 4124-9. 